USING COMMUNICATION TECHNOLOGY 
Also by Bettina S. T. Büchel

INTERNATIONAL JOINT VENTURE MANAGEMENT (with Christiane Prange,

Clemens Rüling and Gilbert Probst)

ORGANIZATIONAL LEARNING: The Competitive Advantage of the Future (with Gilbert Probst) 


\section{Using Communication Technology}

Creating Knowledge Organizations

Bettina S. T. Büchel 


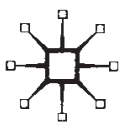

(c) Bettina Büchel 2001

Softcover reprint of the hardcover 1st edition 2001 978-0-333-92950-6

All rights reserved. No reproduction, copy or transmission of

this publication may be made without written permission.

No paragraph of this publication may be reproduced, copied or transmitted save with written permission or in accordance with the provisions of the Copyright, Designs and Patents Act 1988, or under the terms of any licence permitting limited copying issued by the Copyright Licensing Agency, 90 Tottenham Court Road, London W1P OLP.

Any person who does any unauthorized act in relation to this publication may be liable to criminal prosecution and civil claims for damages.

The author has asserted her right to be identified as the author of this work in accordance with the Copyright, Designs and Patents Act 1988.

First published 2001 by

PALGRAVE

Houndmills, Basingstoke, Hampshire RG21 6XS and

175 Fifth Avenue, New York, N.Y. 10010

Companies and representatives throughout the world

PALGRAVE is the new global academic imprint of St. Martin's Press LLC Scholarly and Reference Division and Palgrave Publishers Ltd (formerly Macmillan Press Ltd).

ISBN 978-1-349-42560-0 ISBN 978-0-333-98567-0 (eBook)

DOI $10.1057 / 9780333985670$

This book is printed on paper suitable for recycling and made from fully managed and sustained forest sources.

A catalogue record for this book is available from the British Library.

Library of Congress Cataloging-in-Publication Data

Büchel, Bettina S. T.

Using communication technology : creating knowledge organizations /

Bettina S. T. Büchel.

p. $\mathrm{cm}$.

Includes bibliographical references and index.

1. Information technology. 2. Communication-Technological innovations.

3. Knowledge workers. 4. Organization. I. Title.

HC79.155 B83 2000

$658.4^{\prime} 038-\mathrm{dc} 21$

00-049143

$\begin{array}{llllllllll}10 & 09 & 08 & 07 & 06 & 05 & 04 & 03 & 02 & 01\end{array}$




\section{Contents}

List of Tables

List of Figures

Preface

Acknowledgements

1 Communication Technology and Organizations 1

Communication technology-induced changes in information processing

Communication technology

Relationship between communication technology and organizations: theoretical perspectives

Multiple levels of analysis

2 Knowledge Workers' Choices of Communication Technology

Theoretical perspectives on media choice $\quad 15$

An integrative model of media choice $\quad 32$

Managerial implications $\quad 35$

3 Communication Technology and Organizational Design 41

Features of communication technology 41

The organizational design framework from an information$\begin{array}{ll}\text { processing perspective } & 42\end{array}$

$\begin{array}{ll}\text { Managerial Implications } & 73\end{array}$

4 Communication Technology and Organizational Learning $\quad 81$

$\begin{array}{ll}\text { Organizational learning and information processing } & 81\end{array}$

Media choice $\quad 83$

$\begin{array}{lr}\text { Media choice and organizational learning } & 87\end{array}$

Knowledge development and communication technology 101

Managerial implications 103

5 Communication Technology and Success 114

The relative nature of success $\quad 114$

A framework for measuring communication

technology success 
The chain of communication technology measures

Managerial implications

6 A Dynamic Model of Communication Technology

Employment

Communication technology as a moderating variable $\quad 143$

The dynamic model $\quad 144$

Managerial implications $\quad 148$

Appendix 1 Assumptions about Organizations 153

Appendix 2 Origins of Information Processing 154

Appendix 3 Interview Results for the Comparative Study of the Impact of Communication Technology on Organizations in Nepal, Thailand and Singapore

Appendix 4 A Case Study of Communication Technology Use in Chinese Trademark Agencies 159

Appendix 5 Terminology 162

$\begin{array}{ll}\text { Notes } & 163\end{array}$

Bibliography 167

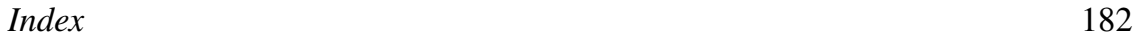




\section{List of Tables}

1.1 Characteristics of various communication technologies 8

2.1 Key determinants of media choice 16

2.2 Media and their features 17

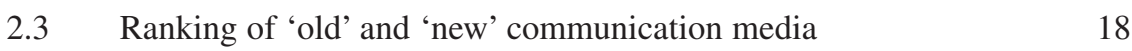

2.4 Features of 'new' communication technology 19

$\begin{array}{lll}2.5 & \text { Task characteristics and key determinants } & 20\end{array}$

2.6 A comparison between rational and social theories of

2.7 The relationship between recipient availability and richness 26

2.8 Social environment characteristics and key determinants 27

2.9 A medium's characteristics and key determinants 28

2.10 Knowledge worker's characteristics and key determinants 31

3.1 Communication technology and centralization or decentralization 48

3.2 Process gains and losses in group decision-making 64

3.3 Communication technology and influence in decision-making 65

$\begin{array}{lll}\text { 3.4 Managers' criteria for centralization versus decentralization } & 75\end{array}$

3.5 The potential of group support systems (GSS) 78

4.1 Match between learning processes, learning situation and media choice 97

4.2 Enabling and constraining forces for communication-

5.1 Computer world index - measure of informationtechnology effectiveness 119

5.2 An example of potential communication technology ratios $\quad 120$

$\begin{array}{ll}5.3 \text { Cost-benefit factors } & 122\end{array}$

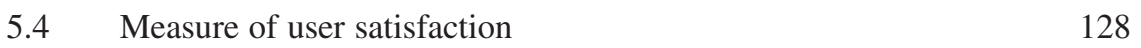

5.5 Usage measures in communication technology 130

$\begin{array}{lll}5.6 & \text { Impact factors } & 132\end{array}$

5.7 Conditional communication technology success measures 135

$\begin{array}{lll}\text { A.2.1 Types of uncertainty } & 154\end{array}$

A.2.2 Types of ambiguity 154

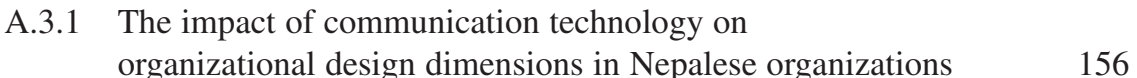

A.3.2 The impact of communication technology on organizational design dimensions in Thai organizations 
A.3.3 The impact of communication technology on organizational design dimensions in Singaporean organizations

A.4.1 Determinants of communication technology usage

A.4.2 Companies in the study

A.4.3 Hardware and software configuration

A.4.4 Networking and database systems implementation 


\section{List of Figures}

1.1 The distinction between 'old' and 'new' communication media 6

$\begin{array}{lll}1.2 & \text { Hierarchical relationship between terms } & 7\end{array}$

1.3 Perspectives of communication technology use in organizations 13

2.1 Conceptual model of media choice 32

2.2 Media selection based on media richness evaluation 36

$\begin{array}{lll}2.3 & \text { Task closure scale } & 37\end{array}$

$\begin{array}{lll}3.1 & \text { Organizational information-processing } & 42\end{array}$

3.2 Vertical information-processing perspective 44

3.3 Horizontal information-processing perspective 56

3.4 The impact of electronic communication on the exchange

$\begin{array}{lll}3.5 & \text { Types of decision-making situations } & 60\end{array}$

3.6 Phases of communication technology penetration 69

3.7 Communication technology transformation of organizations $\quad 71$

4.1 Organizational learning processes $\quad 82$

4.2 The trade-off between media richness and media scope 86

$\begin{array}{lll}4.3 & \text { Media choice determinants } & 87\end{array}$

$\begin{array}{ll}\text { 4.4 Information acquisition and media choice } & 89\end{array}$

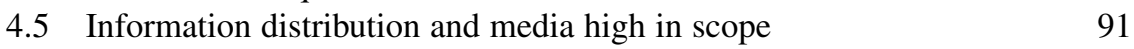

4.6 Information interpretation and rich media 93

4.7 Information storage and media choice 96

4.8 Communication technology potential in knowledge

5.1 Theoretical framework for analyzing communication

5.2 Chain of communication technology measures 133

5.3 Types of user involvement in communication technology implementation 137

6.1 The introduction of communication technology 144

6.2 Communication technology choices by knowledge workers 146

6.3 Dynamic model of communication technology and organizations 


\section{Preface}

My interest in the topic originated with the realization that modern communication technologies are having a profound impact on organizational life. Although I previously did not study communication technology in particular, the focus on this topic is less surprising in the light of my overall interest in organizational change. Given the increasing use of communication technologies in organizations, I wanted to investigate the relationship between these modern technologies and their impact on organizations. Even though communication technology can be approached from a number of different disciplines, the theoretical foundation for this book is derived from the information-processing perspective.

With this book, I intend to inform people interested in or working within organizations about the influence of modern communication technologies on organizational life via creating knowledge organizations. The underlying assumption is that with the increasing employment of new communication technologies, organizations are undergoing change - some of which can be predicted, while other changes are a result of the dynamics involved in the organizational context.

Students or academics interested in the influence of new communication technology will probably enjoy reading the first part of each chapter which summarizes the current empirical findings and the underlying theories. Those that would like to determine the outcome of communication technology employment will prefer the second part of each chapter since it focuses on the managerial implications of the findings.

BETTINA S. T. BÜCHEL 


\section{Acknowledgements}

Writing this book made me realize that with the support of people writing can become an enjoyable task. I particularly benefited from Mrs Yu, a Burmese research associate at the School of Management, Asian Institute of Technology, who helped me in gathering literature, drawing figures and formatting.

I am also grateful for the feedback that I received for earlier drafts of the book, particularly from Raman, a Nepalese doctoral student at the School of Management. He read every chapter several times and looked for inconsistencies and a lack of clarity. With his help, I have tried to simplify the terminology employed throughout the book and included more figures to help the reader making connections between sections.

Without the data gathering of two former MBA students - Ramesh Hamal, a Nepalese, and Cheng Wanxiang, a Chinese - I would not have been able to provide empirical substance to the book. Their work enabled me to draw on the experience of organizations in Asia which serve as examples throughout the book.

During the process of writing this book, I had my second child, Aline. Being pregnant, I had the time needed to focus on writing without being disturbed by other activities that normally accompany a regular faculty job. Since I had my daughter before finishing this book, I feel, however, that she probably suffered most due to the lack of time that I committed to her after she was born. I also wish to thank those people around me who supported me throughout the writing process, especially my husband - Steffen Raub - and my son, Julian.

BetTina S. T. BÜCHEL 